\title{
Feminisme Dakwah Perempuan Dalam Film Habibie \& Ainun 3
}

\author{
Rinta Dwi Anggraini ${ }^{1}$, Ahmad Nurcholis ${ }^{2}$ \\ Institut Agama Islam Negeri Tulungagung ${ }^{12}$ \\ anggrainirinta@gmail.com 1 ,cholisahmad87@gmail.com²
}

\begin{abstract}
Feminism is suspected of being a women's rebellious movement to deny the nature of being a woman and as a driving force to obtain women rights. Feminist ideology demands gender injustice. In preaching, men dominate the spread of Islam than women. Although the implementation of da'wah is predominantly male, there are also many da'iyah in Indonesia, one of which is Ainun. Gender differences do not make Ainun despair in achieving her dream as a doctor. So that this becomes unique to examine. This research uses qualitative methods with a feminist approach. The result of this study was the determine Ainun da'wah massage in the movie Habibie \& Ainun 3, as well as the problems of Ainun as a da'iyah in Indonesia. Ainun can be used as an aspiration and role model for Indonesian people in education, concern, and desire to realize their dreams.
\end{abstract}

Keywords: Feminism, Da'wah, Da'iyah, Movie,

Abstrak: Feminisme diduga menjadi gerakan pemberontak perempuan demi menyangkal fitrah atau kodrat sebagai perempuan serta penggerak untuk memperoleh hak-hak perempuan. Ketidakadilan gender akhirnya dituntut oleh ideologi feminis. Dalam berdakwah laki-laki mendominasi terhadap penyebaran Islam daripada perempuan. Meskipun pelaksanaan dakwah lebih dominan laki-laki, tetapi banyak juga da'iyah di Indonesia salah satunya yaitu Ainun. Perbedaan gender tidak membuat Ainun putus asa dalam meraih impiannya sebagai seorang dokter. Sehingga hal ini menjadi unik untuk diteliti. Penelitian ini menggunakan metode kualitatif dengan pendekatan feminisme. Hasil dari penelitian ini adalah untuk mengetahui pesan dakwah Ainun dalam film Habibie \& Ainun 3, serta problematika Ainun sebagai da'iyah di Indonesia. Ainun dapat dijadikan inspirasi dan panutan bagi masyarakat Indonesia dalam pendidikan, kepeduliannya, serta keinginan untuk mewujudkan impiannya.

Kata Kunci: Dakwah, Da’iyah, Feminisme, Film,

\section{Pendahuluan}

Sebelum Islam datang mendemonstrasikan sebagai agama, peran perempuan terhadap aspek sosial dan pengetahuan sangatlah minim. Bahkan perempuan sebagai status kemanusiaan termalginalkan akibat kemampuan fisik dan mental yang lebih lemah dari laki-laki. Kedatangan Islam memberikan harapan moral bagi kaum perempuan dari berbagai aspek. Namun demikian belum memberikan pengaruh yang signifikan terhadap keadilan kemanusiaan. Hal ini dapat dilihat pada periode awal perkembangan Islam, laki-laki selalu menjadi tumpuan terhadap penyebarannya.

Jauh setelah kemajuan agama Islam, pasca perang dunia II, peran perempuan dalam kemajuan sosial dan sains semakin menunjukkan keterpurukannya. Saat itu pula, muncul gagasan feminisme dalam dunia sains. Gagasan feminisme sendiri merupakan bentuk pembelaan perempuan terhadap ketidakadilan kemanusiaan. Bahkan, gagasan feminisme tersebut menjadi titik balik pembelaan perempuan terhadap penyebaran keagamaan. Muncul beberapa tokoh perempuan yang berpengaruh dalam penyebaran keagamaan (Islam).

Bagi dunia Islam, literatur yang ada menjelaskan bahwa laki-laki mendominasi terhadap penyebaran Islam (Loade, 2010, p. 41). Nabi Muhammad

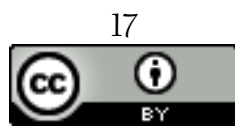

This work is licensed under a Creative Commons Attribution 4.0 International License 


\section{VOLUME 14 NOMOR 1 TAHUN 2021 \\ P-ISSN : 1979-9357 \\ E-ISSN : 2620-5858}

SAW salah satu contoh dari beberapa tokoh yang mampu mempengaruhi peradaban dunia. Tidak hanya terlihat dari dari sejarah peradapan umat Islam saja, tetapi sudah diakui dari tingkat universal. Beliau telah membawa risalah yang agung dari Allah yaitu agama Islam. Selain itu, Beliau dikenal sebagai seorang Nabi yang memiliki pengetahuan yang luas serta mampu mencapai kejayaan yang tinggi pada masa pemerintahnya.

Pada tataran dakwah sebagai salah satu aspek menjalankan kewajiban Islam, tidak ada perbedaan peran antara perempuan maupun laki-laki. Hal tersebut nampak dalam penjelasan al-Quran surat an-Nahl ayat 125. Perempuan maupun laki-laki mempunyai tugas yang sama yaitu mengajak atau menyeru kepada kebaikan dan mencegah kemungkaran. Hal ini menjadi penting untuk di jelaskan, karena selama ini dakwah sering dibatasi dan dipahami sebagai tugas laki-laki. Tidak banyak orang yang paham bahwa dakwah Islam pada dasarnya memberikan porsi yang sama besar terhadap kaum perempuan.

Allah memerintahkan kepada setiap umat Islam agar mengajak dalam kebaikan dan menjauhi larangannya. Apabila dirujuk pada teori pembagian pekerjaan, peran dan tanggungjawab laki-laki dalam melaksanakan dakwah dan kegiatan lainnya lebih dominan dibandingkan dengan peran perempuan. Hal demikian terjadi karena kesanggupan yang dimiliki perempuan lebih rendah dibandingkan dengan laki-laki (Putri, 2018, p. 19). Meskipun pelaksanaan dakwah dominan laki-laki, tetapi banyak juga da'iyah di Indonesia yang salah satunya yaitu Ainun.

Ainun merupakan salah satu tokoh penting dalam film Habibie dan Ainun. Ainun sendiri adalah istri Habibie. Dalam film Habibie \& Ainun 3, sosok Ainun dapat dijadikan sebagai panutan. Selain memiliki paras yang cantik, Ainun merupakan sosok yang gigih dan teguh pendiriannya. Tak hanya itu, ia juga menomorsatukan pendidikan. Sejak kecil Ia bermimpi ingin menjadi seorang dokter. Tetapi pada masa itu, laki-laki lah yang berhak mempunyai cita-cita tesebut dan seorang perempuan dianggap lemah dan tidak pantas menjadi seorang dokter. Banyak yang merendahkan cita-cita Ainun karena perbedaan gender. Tetapi, dengan segala pengorbanan dan tekat yang kuat apa yang ia cita-citakan sejak kecil dapat terwujud.

Film Habibie \& Ainun 3 yang disutradarai oleh Hanung Bramantyo mengisahkan sosok Ainun sebagai seorang muslimah yang patuh terhadap kedua orangtuanya. Sejak kecil ia membantu orang yang akan melahirkan bersama ibunda yang berprofesi sebagai dukun bayi, dengan tantangan yang begitu berat karena tentara jepang mengasai daerah di seluruh pulau Jawa. Ainun sosok perempuan yang tangguh, selalu berusaha. Apapun akan Ia lakukan untuk mewujudkan impiannya. Ia selalu beranggapan bahwa akan ada kesuksesan dimasa yang akan datang. Film sebagai alat untuk menyampaikan pesan kepada khalayak melalui media cerita (Susanto, 2017, p. 3).

Berangkat dari latar belakang di atas, penulis berupaya menangani penelitian secara menyeluruh dalam merespon sebagian permasalahan: pertama, bagaimana pesan dakwah Ainun? kedua, apa problematika Ainun sebagai da'iyah di Indonesia? Bermula dari pertanyaan di atas, penelitian ini akan berguna sebagai dedikasi tinjauan baru mengenai feminisme.

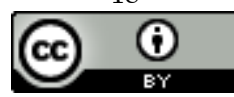

This work is licensed under a Creative Commons Attribution 4.0 International License 
VOLUME 14 NOMOR 1 TAHUN 2021

P-ISSN : 1979-9357

E-ISSN : 2620-5858

\section{Metode}

Penelitian ini menggunakan metode kualitatif dengan pendekatan feminisme (Moleong, 2009, p. 54). Penelitian ini tidak memiliki lokasi karena penelitian ini dilakukan dengan cara melihat dan mengamati film Habibie \& Ainun 3. Waktu yang dibutuhkan kurang lebih 3 bulan (November-januari). Data dalam penelitian ini yaitu film Habibie \& Ainun 3, dan beberapa referensi teori mengenai permasalahan penelitian. Adapun subjek penelitian ini adalah feminisme dakwah Ainun. Penelitian ini memilih film Habibie \& Ainun 3 sebagai objek dari tulisan ini, karena figur Ainun menunjukkan sebagai seorang perempuan yang tangguh. Perbedaan gender tidak menjadi penghalang akan cita-cita yang selama ini ia impikan dan tidak menjadikan perempuan sebagai orang yang lemah.

Analisis data dilakukan dengan mengumpulkan data berupa informasi penting yang diperoleh melalui tontonan juga ditambah dengan sumber sekunder yang mendukung, selanjutnya reduksi data, display data dan penarikan kesimpulan.

\section{Hasil Dan Pembahasan}

\section{Ragam Pendekatan Dakwah}

Sudut pandang atau tolak ukur mengenai proses dakwah adalah pengertian dari pendekatan dakwah. Pendekatan secara umum didasarkan kepada mad'u dan suasana yang meliputinya (Aziz, 2017, p. 297). Pendekatan dakwah merupakan proses yang harus dilakukan da'i atau da'iyah yang digunakan dengan dasar kasih sayang dan kebijaksanaan serta mendapatkan tujuan atau maksud tersendiri.

dua gaya pendekatan dakwah, di antaranya:

a. Pendekatan sosial

Pendekatan sosial menempatkan manusia sebagai makhluk yang mempunyai jiwa sosial dan bergantung pada orang lain. Aspek kehidupan yang termasuk pada pendekatan sosial yaitu:

1) Pendidikan

Pendidikan merupakan kebutuhan yang ada dalam kehidupan bermasyarakat. Pendidikan formal, informal, maupun nonformal bergerak dalam membentuk kecerdasan, kedewasaan, serta membentuk moral manusia yang berakhlakul karimah sebagai subjek dan objek dalam pembentukan manusia.

2) Budaya

Setiap masyarakat memiliki budaya yang beraneka ragam. budaya melambangkan sebagai salah satu karya sekaligus pengikat kebutuhan. Salah satu contoh tohoh ulama yang menggunakan pendekatan budaya dalam berdakwah yaitu walisongo. Pendekatan yang dilakukan walisongo dalam menyelipi ajaran-ajaran dakwah di dalam budaya menjadikan dakwah tersebut lebih mudah di terima oleh masyarakat. Dari pendekatan tersebut walisongo mampu mendapatkan hasil yang cukup baik dalam menarik mad'u.

3) Publik (Politik) 


\section{VOLUME 14 NOMOR 1 TAHUN 2021 \\ P-ISSN : 1979-9357 \\ E-ISSN : 2620-5858}

Pendekatan politik dilakukan lewat kekuasaan. Secara khusus dalam sebuah hadits, Nabi memerintahkan kepada umatnya agar berbuat kebaikan dan mencegah keburukan dengan "fal yughoyyir biyadihi" yang dimaksud yaitu melakukan nahi munkar melalui tangan (kekuasaan) yang dilakukann oleh penguasa. Pendekatan ini dilakukan oleh seseorang yang mempunyai kekuasaan atau jabatan tertentu.

4) Ekomomi

Ekonomi merupakan kebutuhan pokok dalam setiap kehidupan manusia. Kegiatan ekonomi dilakukan sehari-hari demi kelangsungan hidupnya, Pelaksanaan kegiatan dakwah melalui pendekatan ekonomi di masyarakat yang ekonominya rendah yaitu dengan menjadikan kehidupan yang tentram atau bisa juga dakwah melalui perbuatan sebagai keistiqomahan ibadah maupun stabilitas keimanan.

b. Pendekatan Psikologis

Dua perspektif dari pendekatan psikologi, di antaranya:

1) Citra dakwah pada manusia sebagai ciptaan Tuhan yang mempunyai keunggulan dan lebih sempurna dibandingkan ciptaan Tuhan yang lain. Dengan demikian manusia harus menghadapi melalui pendekatan membujuk secara halus supaya yakin, dengan kasih sayang dan kebijaksanaan.

2) Selain mempunyai keunggulan, manusia tentunya mempunyai beraneka ragam keterbatasan maupun kekurangan. Manusia sering menghadapi keputusasaan dalam berkomunikasi dengan dirinya sendiri, di antara kelompok atau publik hingga terjebak pada permasalahan yang mengganggu dirinya.

Dalam dakwah harus mempunyai pandangan bahwa setiap mad'u pasti memiliki problematika. Pendekatan psikologi diperuntukkan kepada mad'u yang membutuhkan pemecahan masalah mengenai kerohanian. Hal ini, dapat dilakukan dengan pengarahan, pelatihan, bimbingan, ataupun menggunakan cara-cara lainnya.

Selain yang telah dipaparkan di atas, terdapat dua pendekatan lain dalam berdakwah. Pertama, pendekatan dakwah berpusat pada pendakwah. Pada pendekatan ini disesuaikan oleh kemampuan seorang da'i. Da'i harus mengetahui pesan dakwah apa yang akan disampaikan pada mad'u dan media apa yang akan digunakan dalam berdakwah. Kedua, pendekatan berpusat pada mitra dakwah (mad'u). Pendekatan yang dipusatkan pada mad'u ini, lebih fokus pada unsurunsur dakwah dalam menerima pesan dakwah. Pemahaman mad'u pada pesan dakwah lebih ditekankan dari psikomotorik maupun perilaku mereka. Oleh karena itu, target yang harus dicapai adalah kelangsungan dalam berdakwah (Aziz, 2017, p. 348).

Salah satu bentuk media dakwah adalah film. Hampir seluruh masyarakat Indonesia gemar menonton fim dan mendapat peringkat ketiga setelah kegemaran di bidang olahraga dan musik. Dakwah melalui media film sangat dibutuhkan dan perlu dikembangkan. Melalui film yang dikemas secara menarik dan modern, dimuat di media massa maka pesan dakwah yang berada dalam film lebih tersebarluaskan secara mudah dan dapat diterima oleh seluruh masyarakat. 


\section{VOLUME 14 NOMOR 1 TAHUN 2021 \\ P-ISSN : 1979-9357 \\ E-ISSN : 2620-5858}

Seorang da'i dalam berdakwah harus mengetahui metode dakwah yang akan digunakan. Metode dakwah juga diartikan sebagai usaha yang telah direncanakan untuk mendapatkan tujuan yang diinginkaan (Suparta \& dan kawan-kawan, 2009, p. 6). Metode dakwah merupakan ilmu yang mengajarkan peraturan pada dakwah yang berguna untuk menggapai tujuan dakwah semaksimal mungkin (Abdullah, 2018, p. 134). Metode dakwah banyak ragamnya, salah satunya adalah dakwah bil hal. Maksudnya adalah dakwah dilaksanakan melalui berbaneka ragam kegiatan nyata dalam kehidupan sehari-hari dan dapat menyentuh hati masyarakat secara langsung (Oktaviana, 2020, p. 30).

\section{Perempuan Sebagai Da'iyah}

Da'i atau da'iyah membutuhkan dakwah untuk menjalankan kegiatan dakwah. Da'i adalah orang yang berdakwah dengan menyampaikan ajaran Islam yang dilakukan melalui lisan tulisan, maupun perbuatan. Dapat dilaksanakan secara individu, kelompok maupun lembaga (Aziz, 2017, p. 75). Da'iyah memiliki dua perspektif, yaitu:

a. Dalam artian sempit, Da'iyah diartikan sebagai penyampaian ajaran Islam yang dilakukan perempuan kepada manusia baik dilakukan melakui tulisan, lisan, ataupun gambaran.

b. Dalam artian luas, Dai'yah diartikan sebagai orang yang menafsirkan, menterjemahkan, maupun menjalankan ajaran Islam dalam kehidupannya.

Selain disebut da'iyah, pendakwah juga disebut sebagai muballigh atau muballighah. Secara umum, menjadi seorang da'iyah membutuhkan beberapa sifat, yaitu:

a. Mendalami al-quran, sunnah dan histori kehidupan Nabi Muhammad SAW dan Khulafaurasyiddin.

b. Berani dalam menyampaikan kebenaran dimanapun dan kapanpun.

c. Paham terhadap kondisi mad'u.

d. Satu kata dengan perbuatan

e. Ikhlas dalam melakukan tugas dakwah dan tidak tergiur dengan kenikmatan maupun materi semata.

f. Terjauhkan dari segala hal yang dapat menjatuhkan harga diri.

Pelaksanaan dakwah sebagaimana tertulis pada surah At-Taubah ayat 71 dibagi menjadi dua yaitu kelompok atau perorangan. Selain laki-laki, perempuan juga memiliki kewajiban yang sama terhadap perintah dakwah. Karena penunaian tugas itulah mereka dikatakan sebagai sebaik-baik umat (Sakdiah, 2013, p. 11). Dalam penyampaian pesan dakwah da'iyah membawa pengaruh yang besar dalam masyarakat.

Ainun salah satu perempuan Indonesia yang yang berdakwah dengan perbuatan. Perbuatan yang Ia lakukan dalam film Habibie \& Ainun 3 merupakan perbuatan baik yang cenderung melakukan hal-hal yang bernilai positif. Selain itu, usaha yang di lakukan dalam mengejar impiannya sebagai seorang dokter yang bisa membantu orang lain menjadi cita-cita yang mulia.

\section{Pesan Dakwah Ainun Dalam Film Habibie \& Ainun 3}

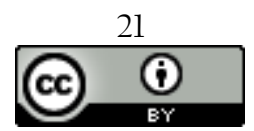

This work is licensed under a Creative Commons Attribution 4.0 International License 


\section{VOLUME 14 NOMOR 1 TAHUN 2021 \\ P-ISSN : 1979-9357 \\ E-ISSN : 2620-5858}

Pesan merupakan bagian signifikan yang disampaikan oleh komunikator (Effendi, 2003, p. 18). Sedangkan dakwah menurut Ali Mafudz diartikan sebagai suatu upaya mendorong manusia untuk melakukan kebajikan dan mengikuti petunjuk dari Allah SWT, berusaha mengajak pada kebiasaan-kebiasaan yang baik dan melarang dari kebiasaan-kebiasaan yang buruk agar memperoleh kesuksesan di dunia dan akhirat (Sholihah, 2011, p. 23).

Pesan dakwah merupakan unsur penting pada pelaksanaan dakwah. Kegiatan dakwah dapat dikatakan efektif apabila materinya bersifat edukatif, informatif, mupun solutif bagi mad'u. Seorang da'i dalam penyampaian pesan dakwah diharuskan memiliki keterampilan yang baik dalam berkomunikasi. Pada al-quran terdapat enam istilah qaulan (perkataan) yang menjadi panduan seorang muslim dalam berkomunikasi (Husen, 2017, p. 47), yaitu:

a. Qoulan Ma'rufa (ucapan baik)

Maksud dari qoulan ma'rufa yaitu ucapan yang pantas diucapkan oleh orang yang mengucapkan (komunikator) maupun orang yang diajak berbicara (komunikan). Selain itu, qoulan ma'rufa juga dipahami sebagai kalimat yang baik, ketika kalimat tersebut beretika, tidak berlawanan pada norma maupun nilai agama.

Salah satu contoh qoulan ma'rufa yang dilakukan Ainun dalam film Habibie \& Ainun 3 terjadi pada dialog scene 01:37:38. Ainun: "Aku ingin membangun negaraku apapun keadaannya". Perkataan tersebut diucapkan Ainun ketika Ahmad suatu hari nanti ingin mengajaknya keluar negeri, hidup bersama dengannya. Tetapi Ainun menolak karena ia ingin memajukan negarannya sendiri.

b. Qaulan sadida (ucapan yang benar)

Qoulan sadida yaitu meruntuhkan sesuatu kemudian memperbaikinya. Perkataan yang meruntuhkan, jika disampaikan harus ada usaha untuk memperbaikinya. Maksudnya kritikan tersebut merupakan kritikan yang bersifat membangun, informasinya pun harus mendidik tidak hanya meluruskan kesalahan.

Qoulan sadida yang dilakukan Ainun dalam film Habibie \& Ainun 3 pada dialog scene 52:39. Ainun: "Saya bisa menuntut anda dengan pasal mengganggu kenyamanan orang". Perkataan tersebut diucapkan Ainun, ketika Ahmad salah satu mahasiswa hukum yang berusaha merayunya. Perilaku Ahmad membuat Ainun risih dan merasa terganggu.

c. Qaulan baliga (berdampak dan efektif)

Qaulan baliga yaitu, ucapan yang dapat berpengaruh dan menyentuh hati kepada orang yang diajak berbicara. Maksudnya yaitu bahasa yang dilakukan dalam berkomunikasi, dapat mempengaruhi dan dapat mengubah perilaku pada lawan bicaranya.

Qoulan baligha yang dilakukan Ainun dalam film Habibie \& Ainun 3 di dialog scene 45.22. Ainun: "Duduk di bawah saja! Kita disini jadi dokter bukan mencari menang kalah.. sekarang kita lagi belajar untuk mengalah, ikhlas karena itu yang harus kita berikan ke pasien kita". Perkataan tersebut diucapkan Ainun ketika Tempat duduk di kelas Ainun tidak mencukupi, salah satu mahasiswa yang tidak kebagian tempat duduk menggeser

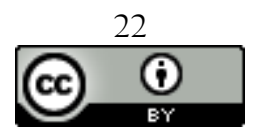

This work is licensed under a Creative Commons Attribution 4.0 International License 


\section{VOLUME 14 NOMOR 1 TAHUN 2021 \\ P-ISSN : 1979-9357 \\ E-ISSN : 2620-5858}

mahasiswa lain sehingga terjadilah pertikaian. Ainun berusaha meredam dengan mewakili duduk dibawah. Karena ucapan dan tindakannya, teman-teman sekelas Ainun meniru dan menghormatinya dengan ikut duduk dibawah.

d. Qaulan karima (ucapan yang mulia)

Qaulan karima adalah ucapan yang santun, mulia, pengagungan, memiliki tata karma sebagai penghormatan terhadap lawan berbicara. Komunikasi ini merupakan jenis komunikasi yang dilakukan ketika berbisara dengan orang yang lebih tua, seperti orangtua maupun guru.

Salah satu contoh qoulan karima yang dilakukan Ainun dalam film Habibie $\&$ Ainun 3 terjadi di dialog scene 01:10:50. Ainun: "profesr Husodo!" (menundukkan pandangannya). Dari perkataan dan gerak tubuh yang dilakukan Ainun ketika kaget mengetahui bahwa Prof. Husodo adalah ayah kandung Ahmad, Ainun menundukkan pandangannya mengisyaratkan kepatuhan seorang murid terhadap gurunya.

e. Qaulan maisura (mudah dipahami)

Qaulan maisura menurut Al-Sabuni dalam safwah al-tafasir adalah ucapan yang halus, mudah dipahami, mudah dimengerti, dan mudah diserap disertai dengan janji kepada mereka. Sedangkan menurut Ibnu Katsir qaulan maisura adalah ucapan yang pantas, tepat, serta janji menyenangkan dengan memberikan harapan positif terhadap pihak yang diberi janji.

Qoulan maisura yang dilakukan Ainun dalam film Habibie \& Ainun 3 pada dialog scene 01:49:16. Ainun: "Saya hanyalah seorang Indonesia.bagian dari bangsa Indonesia. Mungkin masih muda ,masih perlu belajar banyak, tapi memiliki cita-cita dan impian yang besar. Untuk bangkit berdikari menjadi masyarakat yang sejahrera. Saya, kita semua akan menjadi bagian dari bakti itu". Perkataan itu dilontarkan ketika Ainun berada di atas podium menjadi lulusan terbaik fakultas kedokteran. Ucapannya membuat banyak perhatian dan membuat orang lain bangga kepadanya.

f. Qaulan layyina (lemah lembut)

Qaulan layyina adalah ucapan lemah lembut. Apabila berkomunikasi menggunakan kata-kata yang halus, lemah lembut, tidak kasar, bahkan ketika menasehati orang (komunikan) menggunakan bahasa sindiran (bukan makna sebenarnya), sehingga lebih mudah diterima oleh orang yang diajak berbicara.

Contoh qoulan layyina yang dilakukan Ainun dalam film Habibie \& Ainun 3 terjadi pada dialog scene 01:18:55. Ainun: "jadi, kerumah sakit atau ke klinik kesehatan adalah tempat bagi siapapun untuk melakukan pengecekan terhadap tubuh mereka. Justru sebelum ketahuan sakit”. Perkataan ini diucapkan Ainun ketika Ahmad menganggap bahwa rumah sakit atau klinik kesehatan untuk orang yang sakit. Tetapi, Ainun berusaha meyakinkan Ahmad dengan lemah lembut atas pernyataannya bahwa klinik kesehatan atau rumah sakit tidak hanya untuk mengobati orang-orang yang sedang sakit, melainkan mengecek kesehatan tubuhnya sebelum sakit.

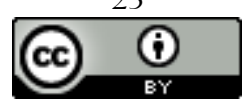

This work is licensed under a Creative Commons Attribution 4.0 International License 


\section{VOLUME 14 NOMOR 1 TAHUN 2021 \\ P-ISSN : 1979-9357 \\ E-ISSN : 2620-5858}

Keenam jenis komunikasi yang telah dijelaskan di atas, ternyata dapat digunakan untuk mengetahui dan memahami komunikasi yang terjadi dalam film Habibie \& Ainun 3 pada prosen penympaian pesan-pesan dakwah.

\section{Pobrematika Ainun Sebagai Da'iyah Di Indonesia}

Problematika berawal dari kata "problem" yang berarti suatu masalah, problema, soal, dan teka-teki (K, 2003, p. 342). Problematika dapat pula diartikan sebagai perbuatan yang dapat menjadikan suatu persoalan, dan permasalahan dalam keadaan tertetu. Problematika sangat beragam dalam sebuah kehidupan manusia. Hal ini membuat pendakwah harus siap menghadapi berbagai macam problematika. Ada dua pokok persoalan dakwah pada kehidupan manusia, di antaranya:

a. Pergantian nilai Islam yang berakibat dinamisme, rasionalisme, matrealisme, dinamisme, kepitalisme, perilaku yang berpengaruh, pemisahan diri, individualistik.

b. Lahirnya berbagai macam persoalan seperti kesengsaraan, kekerasan dalam bermasyarakat, keterbelakangan, dan dekadensi sosial.

Di Indonesia, umat mempunyai beberapa persoalan mendesak dan harus diatasi, persoalan (Muhyidin, 2014, p. 124) tersebut di antaranya:

a. Pemahaman agama yang masi lemah.

b. Kemiskinan dan masyarakat yang bercerai-berai.

c. Kejahatan dan perbuatan hukum dan norma yang berlaku.

d. Lemahnya SDM dan meningkatnya penduduk dalam jumlah drastis.

e. Rusaknya lingkungan.

Ainun dalam film Habibie \& Ainun 3 lebih cocok dikatakan sebagai panutan daripada seorang da'i. hal ini dikarenakan penampilan dalam berpakaian Ainun kurang memenuhi syarat penampilan sebagai seorang da'i. Seorang da'i perempuan memiliki kewajiban menutup aurat seluruh tubuhnya selain telapak tangan dan wajah. Selain itu perilaku Ainun dalam film tersebut menceritakan percintaan semasa mudanya dengan Ahmad. Padahal agama Islam tidak memperbolehkan pacaran. Tetapi dalam hal Perbuatan yang dilakukan dalam film tersebut memiliki nila-nilai positif yang dapat dijadikan inspirasi.

Secara umum, Ainun dapat menjadi panutan bagi masyarakat Indonesia khususnya dalam hal pendidikan. Ia berusaha meraih cita-citanya sebagai seorang dokter yang saat itu banyak orang meremehkan cita-citanya karena ia seorang perempuan. Berkat kegigihan dan semangat yang kuat ia diterima kuliah di Universitas Indonesia. Hingga bekerja di RS Cipto Mangunkusumo (RSCM).

Selain itu, Ainun dijadikan sebagai model bagi keluarga Indonesia dalam membangun rumah tangganya dengan kasih sayang dan keharmonisan bersama B.J.Habibie. Kegiatan gerakan kebaikan keluarga Indonesia yang selenggarakan di Bogor pada tanggal 24 Juli 2016 memberikan penghargaan kepadanya dengan julukan "Sang Inspirasi Keluarga" oleh pekumpulan pegiat keluarga (GiGa) (Republika, 2020). Ainun salah satu perempuan nasionalis di Indonesia. Hal ini dapat dilihat ketika B.J.Habibie telah diangkat menjadi presiden, Ainun menjadi ibu negara yang harus mendampingi sang suami. Bahkan ia rela beralih profesi dari

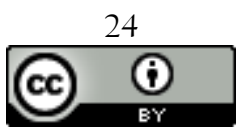

This work is licensed under a Creative Commons Attribution 4.0 International License 


\section{VOLUME 14 NOMOR 1 TAHUN 2021 \\ P-ISSN : 1979-9357 \\ E-ISSN : 2620-5858}

seorang dokter menjadi ibu rumah tangga. Karena kesetiaan Ainun pada suaminya mereka menjadi sorotan masyarakat.

Selain sebagai ibu negara, Ainun juga bergerak sebagai pahlawan kesehatan yang berjuang untuk mengembalikan penglihatan penyandang tunanetra. Ia mendirikan bank mata supaya para tunanertra bisa melihat kembali dengan normal, walaupun hal tersebut masih menjadi pro kontra dengan pemerintah. Masih banyak kendala donor mata terutama pada norma agama. Bukanlah hal mudah untuk mendapatkan sertifikasi halal dari Majelis Ulama Indonesia (MUI) mengenak hukum Donor mata ini. tetapi Ainun terus berusaha agar bisa memperjuangkan peraturan yang tepat terhadap donor mata hingga mendapat putusan halal dari MUI. Kebaikan yang dilakukan Ainun tidak dapat dilihat dengan uang. Tetapi, orang yang matanya cacat akan besar hati terhadap sosok Ainun. karena ia telah membantu dalam mengembalikan pengelihatannya. Jasa Ainun kini dikenang oleh Prof. Dr dr Nila F Moeloek, SpM(K) selaku menteri kesehatan dan masyarakat yang telah dibantunya.

Pemerintahan Gorontalo membangun dan meresmikan rumah sakit Provinsi dr. Hasri Ainun Habibie di Limboto kabupaten Gorontalo pada tahun 2013. Penamaan tersebut diberikan pada Ainun karena berkat sumbangsihnya pada dunia kesehatan khususnya penanganan penyakit mata yang ada di Indonesia (Liputo, 2020). Rumah sakit tersebut menjadi rumah sakit rujukan daerah wilayah Gorontalo, Sulawesi Utara, dan Sulawesi Tengah. Rumah sakit tersebut, saat ini diberi nama menjadi Universitas negeri Gorontalo dan sedang dalam proses pengembagan menjadi rumah sakit pendidikan.

\section{Kesimpulan}

Feminisme dakwah dalam film Habibie \& Ainun 3 dilakukan oleh tokoh yang bernama Ainun. Ia dapat menginspirasi seseorang untuk berpendidikan tinggi dan mengejar cita-citanya sebagai seorang dokter yang pernah diremehkan banyak orang. Selain itu, kepedulian Ainun terhadap orang lain bisa dijadikan sebagai panutan dan pelajaran yang baik. Ainun lebih cocok dikatakan sebagai panutan daripada seorang da'i. karena penampilan berpakaian Ainun kurang memenuhi syarat penamilan seorang da'i. Selain itu, karena cerita percintaan semasa mudanya dalam film tersebut. Secara universal Ainun dapat dijadikan inspirasi dan panutan bagi masyarakat Indonesia dalam pendidikan, kepeduliannya terhadap sesama dengan mendirikan bank mata maupun keharmonisan dan cinta kasihnya dalam membangun rumah tangga.

\section{Daftar Pustaka}

Abdullah. (2018). Ilmu Dakwah: Kajian Ontologi, Epistemologi, Aksiologi Dan Aplikasi Dakwah. Depok: Rajawali Press.

Aziz, A. M. (2017). Ilmu Dakwah (7 ed.). Jakarta: Kencana. 
VOLUME 14 NOMOR 1 TAHUN 2021

P-ISSN : 1979-9357

E-ISSN : 2620-5858

Effendi, O. U. (2003). Ilmu Komunikasi Dan Teori Praktek (17 ed.). Bandung: PT. Remaja Rosdakarya.

Husen, H. (2017). Metode Ta'dib Dan Komunikasi Islam Menurut Perspektif AlQur'an Dan Hadits Dalam Pembangunan Karakter Anak Usia Dini. 1(2).

K, S. (2003). Kamus Lengkap Bahasa Indonesia. Surabaya: Cipta Karya.

Liputo, M. (2020, Desember 20). dr. Hasri Ainun Habibie Resmi Rumah Sakit Pemerintah Provinsi Gorontalo.

Loade, K. M. (2010). On Islamic Civilization. Semarang: Unnisula Press.

Moleong, L. J. (2009). Metode Penelitian Kualitatif. Bandung: PT. Remaja Rosdakarya.

Muhyidin, A. (2014). Kajian Dakwah Multiperspektif: Teori, Metodologi, Problem, Dan Aplikasi. Bandung: Remaja Rosdakarya.

Oktaviana, W. (2020). Dakwah Bil Hal Sebagai Metode Pada Masyarakat Srikaton Seputih Surabaya Kabupaten Lampung Tengah. Lampung: IAIN Metro.

Putri, T. N. (2018). Peran Da'iyah Dalam Penyampaian Pesan Dakwah (Studi Pada Ormas Muhammadiyah Cabang Banda Aceh). Banda Aceh: UIN Ar-Raniry Press.

Republika. (2020, Desember 20). Ainun-Habibie Jadi Teladan Keluarga Indonesia . Retrieved from https://m.republika.co.id

Sakdiah. (2013). Peran Da’iyah Dalam Perspektif Dakwah. Banda Aceh: Bandar Publishing.

Sholihah, S. Q. (2011). Analisis Pesan Dakwah Dalam Film Mihrab Cinta. Jakarta: UIN Syarif Hidayatullah.

Suparta, M., \& dan kawan-kawan. (2009). Metode Dakwah (3 ed.). Jakarta: Kencana.

Susanto, O. (2017). Representasi Feminisme Dalam Film ‘SPY”. Jurnal EKomunikasi, 5(1). 